\title{
Geopolitikai irányváltások a kialakulóban lévő új világrendben*
}

\author{
Szapáry György - Plósz Dániel János
}

A közelmúlt geopolitikai fejleményei egy többpólusú, új világrend irányába mutatnak. A kereskedelem nemzetközivé válása és a modern technológia elterjedése által előidézett globalizáció radikálisan megváltoztatta a világhatalmak befolyását. Egy vezető állam ma sokkal inkább képes kiterjeszteni befolyását és világszerte érvényesíteni érdekét. Jelen tanulmány bemutatja egy ország világhatalommá válásának fö feltételeit a jelenlegi, globalizált világban, és megvizsgálja, hogy mely országok felelnek meg azoknak a feltételeknek, amelyek megalapozzák és lehetővé teszik uralkodó szerepüket a kialakulóban lévő új világrendben. A szerzők végül arra a következtetésre jutnak, hogy leginkább Kína van abban a helyzetben, hogy megtörje az Egyesült Államok kizárólagos gazdasági dominanciáját. Az Európai Unió nem használja ki súlyát a globális politikák befolyásolásában, és kérdéses, hogy képes lesz-e, illetve szándékozik-e magára vállalni egy világhatalom felelősségét. A Visegrádi Négyek országainak és a többi közép- és kelet-európai országnak - az Európai Unió és a NATO tagjaként, a Keletet és Nyugatot összekötő utak mentén elhelyezkedve - alapvetö érdekük, hogy elgondolkodjanak az elöttünk álló évtizedekben várható geopolitikai változásokról.

Journal of Economic Literature (JEL) kódok: O10, O20, O30

Kulcsszavak: uralkodó szerep, világrend, Visegrádi országok, Amerikai Egyesült Államok, Kína, Oroszország

\section{Bevezetés}

A közelmúlt geopolitikai fejleményei egy többpólusú új világrend irányába mutatnak. Kína felemelkedése és gazdasági világhatalommá válása, továbbá Oroszország újra megtalált magabiztossága megkérdőjelezi az - eddig az Egyesült Államok által uralt és általánosságban nem vitatott - egypólusú világrendet. Világszerte, és ma-

* A jelen kiadványban megjelenő írások a szerzők nézeteit tartalmazzák, ami nem feltétlenül egyezik a Magyar Nemzeti Bank hivatalos álláspontjával.

Szapáry György a Magyar Nemzeti Bank elnökének fötanácsadója. E-mail: szaparygy@mnb.hu Plósz Dániel János a Központi Statisztikai Hivatal osztályvezetője. A cikk írásakor a Magyar Nemzeti Bank közgazdásza volt.E-mail: Daniel.Plosz@ksh.hu

Az esszé a szerzők nézeteit tartalmazza, amelyek nem feltétlenül egyeznek a Magyar Nemzeti Bank nézeteivel. Az angol nyelvű kézirat 2019. július 12-én érkezett szerkesztőségünkbe.

DOI: http://doi.org/10.25201/HSZ.18.4.112129 
gának az Egyesült Államoknak az egyes területein is sokan érzékelik, hogy Amerika vezető szerepe meggyengült. A geopolitikai változások azonban többnyire lassúak, és nemritkán akár több évszázadba is telt, mielőtt egy uralkodó világhatalmat egy másik váltott fel. Volt, amikor a változás viszonylag békésen ment végbe, máskor pedig brutális háború eredményeképpen alakult ki. Az ókorban a vezető államok hatalma és befolyása a világ mostani mércéje szerint regionális szintű volt. Athén és Róma alapvetően a földközi-tengeri medencét uralta, amit a rómaiak kiterjesztettek Európa középső és északi részeire. Az Oszmán Birodalom virágzása idején Nyugat-Ázsiától Európa és Afrika egyes részeiig terjedt. Ezek hatalmas és sűrűn lakott területek voltak, eltérő nyelveket beszélő, különböző kultúrákhoz tartozó népességgel. A régiót jogosan tekintik a civilizáció „bölcsőjének”, bár az ókori Kína nyugati civilizációhoz való hozzájárulását is el kell ismerni. ${ }^{1}$ Mindazonáltal ezek az ókori birodalmak a bolygónk csak egy kis része felett uralkodtak.

A XIX. században és a XX. század első felében Nagy-Britannia közel került ahhoz, hogy a mai mérce szerint is uralkodó világhatalommá váljon, mivel gyarmatokkal rendelkezett Ázsiában, Afrikában, a Karib-térségben és Óceánia egyes területein, meghatározó volt jelenléte a tengereken, és döntő szerepet játszott a nemzetközi kereskedelemben, valamint a pénzügyi világban, tekintve hogy a font sterling nemzetközi tartalékvalutaként funkcionált. A II. világháborút követően hirtelen megszűnt uralkodó szerepe, miután elveszítette gyarmatait, az Egyesült Államok pedig fölényt szerzett a tengereken, a nemzetközi kereskedelemben és a pénzügyi életben, továbbá az innováció és a technológia terén, valamint az amerikai dollár lett a világ általánosan elfogadott tartalékvalutája. A Szovjetunió 1991-ben bekövetkezett szétesését követően az Egyesült Államok az emberiség történelmében addig példátlan módon vált a világ egyedüli uralkodó hatalmává.

A kereskedelem nemzetközivé válása és a technológia terjedése által előidézett globalizáció radikálisan megváltoztatta a világhatalmak befolyását. Egy vezető állam ma sokkal inkább képes kiterjeszteni befolyását és világszerte érvényesíteni érdekét. Ily módon a befolyásért vívott harc most már globális szinten folyik, de csak néhányan próbálkoznak komoly kihívó szerepet vállalni. Egyetlen tekintélyes gondolkodó sem állítaná azt, hogy a közeljövőben Amerika megszűnik uralkodó világgazdasági hatalomnak lenni, de ettől még tény, hogy a világrendben betöltött viszonylagos befolyása a kihívók megjelenésével csökken. Amerika egyedüli vezető szerepét egyre inkább vitatják, vagy legalábbis nem tartják magától értetődőnek.

Számos szerző tanulmányozta a világhatalmak felemelkedését és hanyatlását. Szilágyi István (2018) átfogó képet nyújt a geopolitikai elméletről és erre vonatkozóan kiterjedt irodalmat tekint át. Rámutat, hogy a termelés, a kereskedelem és a tenge-

${ }^{1}$ Kína számos innováció forrásául szolgált, hogy csak a legismertebbeket - papírgyártás, nyomtatás, puskapor, iránytű - említsük. 
rekhez való hozzáférés fontosságát Friedrich Ratzel (1897) már a XIX. század második felében felismerte. Ratzel öt nagyhatalmat említett - Anglia, Oroszország, Kína, az Egyesült Államok és Brazília - és kifejtette a két vezető hatalmat (az Egyesült Államokat és Oroszországot) védő Európai Közösségre vonatkozó ötletét. Szilágyi azt is megemlíti, hogy Rudolf Johan Kjellén (1917) különbséget tett a világhatalommal és az európai befolyással rendelkező vezető államok között, és véleménye szerint az Osztrák-Magyar Monarchia az utóbbiak közé tartozott.

George Modelski (1988) kidolgozott egy hosszú-ciklus elméletet, amely megpróbálja megragadni a világhatalmak múködési szabályszerűségeinek elemeit. Kapcsolatot lát a háborús ciklusok, a gazdasági fölény és a világban betöltött vezető szerep között. Véleménye szerint 1500 óta öt ciklus létezett, amelyek mindegyike egybeesett valamely hatalom hegemóniájával: Portugália hegemóniáját tapasztaljuk a XVI. században, Hollandiáét a XVII. században, Nagy-Britannia a XVIII. és XIX. században, az Egyesült Államok a XX. században volt ilyen helyzetben. William Thompson (1988) és Paul Kennedy (1988) szintén a nagy háborúkat és a gazdasági erőt emelték ki a globális vezető szerep emelkedésében és hanyatlásában.

Zbigniew Brzezinski (2012:75-76) már Amerika globális vonzerejének halványulásáról és nemzetközi befolyásának csökkenéséről beszél. Azt írja, hogy „ha Amerika megtorpan, nem valószínü, hogy a világot egyetlen kimagasló utód, mint Kína, fogja uralni”. Ehelyett „egy elfogadott vezető hiányában keletkező bizonytalanság, valószínúsíthetően növeli majd a versenytársak közötti feszültséget, és önző magatartásra ösztönöz". Ezen érvelés alapjául a szerzőnek az a meggyőződése szolgál, hogy a világrend fenntartásához Amerikának erősnek kell maradnia. Hasonló aggályok bukkannak fel Robert Kagan (2012:130) gondolataiban. Az ő legnagyobb aggodalma „nem igazán az, hogy az Egyesült Államok megengedheti-e magának, hogy továbbra is betöltse jelenlegi szerepét a világban, hanem az, hogy az amerikaiak képesek-e megoldani a legégetőbb gazdasági és társadalmi problémáikat". Ez lényeges szempont, ugyanis sok birodalom belső viszályok következményeképpen bomlott fel, amelyek meggyengítették és külső beavatkozás célpontjává tették őket. Henry Kissinger (1979) az Egyesült Államokat a világbéke letéteményesének tekintette, és Richard Nixon elnökkel egyetemben hamar felismerte, hogy Amerikának diplomáciai kapcsolatokat kell létesítenie Kínával, mint a kelet-ázsiai amerikai befolyást potenciálisan veszélyeztető országgal, amely azonban egyben potenciális partner is a Szovjetunió területi törekvéseinek letörésében.

George Friedman (2012) azzal érvel, hogy az Egyesült Államoknak nem állt szándékában birodalommá válni: a világban szerzett uralkodó szerepe bizonyos események következménye, amelyek többségére Amerikának nem volt ráhatása. Ennek kevés köze van a valósághoz. Ahhoz, hogy egy ország nagyhatalommá váljon, rendelkeznie kell bizonyos objektív földrajzi adottságokkal, és ha olyan szerencsés, hogy birtokolja azokat, ahogy Amerika, akkor a népének és vezetőinek törekvése fogja az országot 
vezető állammá tenni. Kagannak (2012) igaza van abban, hogy az Egyesült Államok magatartása, nem igazán illik a „vonakodó seriff” képébe, aki csak azért háborúzik, mert muszáj neki. Sokszor azért lépett háborúba, hogy távoli fenyegetésektől védje meg magát, és fenntartsa gazdasági érdekeltségeit Kubában a spanyolokkal, illetve Indokínában a kommunistákkal szemben, valamint a Közel-Keleten.

A jelen tanulmány célja, hogy áttekintse azokat a legfontosabb feltételeket, amelyek ahhoz szükségesek, hogy egy ország világhatalommá váljon a jelenlegi globalizált világban, és megvizsgálja, hogy mely országok felelnek meg azoknak a feltételeknek, amelyek alapul szolgálnak ahhoz, hogy a kialakulóban lévő új világrendben uralkodó szerepet töltsenek be.

\section{A világhatalommá válás feltételei}

A méret számít. A szilárd alapon nyugvó, nagy és robusztus gazdaság elengedhetetlen feltétele annak, hogy megvalósuljanak azok az álmok, amelyek a világ vezető hatalmává válásával kecsegtetnek. Egy gazdaság méretének meghatározására használt legelterjedtebb mutató a GDP. A GDP függ az országban dolgozók számától, így számít a népesség mérete. Emellett a GDP függ a munkások termelékenységétől, amit viszont az alkalmazott technológia határoz meg. Az innováció és a legmodernebb technológiák alkalmazása terén világvezető országok a legsikeresebbek a termelékenység növelésében és versenyelőnyük megőrzésében az áruk és szolgáltatások piacán. Az innováció szakértelmen alapul, amit minőségi oktatás útján lehet leginkább megszerezni. Egy világvezető szerepért versengő ország számára elengedhetetlen egy olyan oktatási rendszer, amely képes olyan szakembereket képezni - a legalacsonyabbtól kezdve a legmagasabb képesítési szintig -, akik a jövő munkáit a legjobban el tudják végezni.

A vezető államok leginkább a kereskedelmen keresztül érvényesítik befolyásukat. A keresett áruk és szolgáltatások termelésén alapuló változatos és versenyképes export, amit más országok importálnak, befolyást biztosít az exportőr ország számára. A nagymennyiségű és változatos természeti kincsek birtoklása szintén előny, mivel csökkenti a másokra való ráutaltságot a nyersanyagok tekintetében, ráadásul értékes exportcikk is lehet. Minél nagyobb egy ország területe, annál valószínúbb, hogy rendelkezik természeti kincsekkel. Továbbá, egy ország mérete abban a tekintetben is számít, hogy képes nagyszámú népességnek otthont adni.

Más jellemzők is relevánsak. Ha egy ország valutáját széles körben használják nemzetközi fizetőeszközként, a jelenlegi globalizált világban az jelentős előnyöket eredményez a kibocsátó számára, „szerfölötti kiváltságot” (exorbitant privilege), ahogy Valéry Giscard d’Estaing utalt rá, amikor Franciaország pénzügyminisztere volt. Barry Eichengreen (2011) kiválóan bemutatja az amerikai dollár vezető szerepbe kerülését a nemzetközi kereskedelemben és adósságfinanszírozásban, valamint 
globális tartalékvalutává válását. Emellett rávilágít azokra az előnyökre is, amelyek az Egyesült Államok számára az erőfölényből származnak a seigniorage, az alacsony kamatlábak és a magas költségvetési és folyófizetésimérleg-hiány finanszírozására való képesség formájában. Az erősödő nemzetközi pénzügyi integráció valójában növelte a rendszer amerikai dollártól való függését, ami az Egyesült Államok számára lehetővé tette, hogy a globális pénzügyi rendszert saját biztonsági céljainak szolgálatába állítsa (Leonard et al. 2019). Ennek egyik példája az Egyesült Államok által Iránra kivetett szankciók.

Egy nemzeti valuta nemzetközileg dominánssá válásának elengedhetetlen feltételei vannak. Először is, kellően nagy mennyiségben kell rendelkezésre állnia ahhoz, hogy zökkenőmentessé tegye a nemzetközi ügyleteket, és a piacoknak bízniuk kell a valuta stabilitásában. Csak a nagy és erős gazdaságok képesek megfelelni e feltételeknek. Másodszor, a valutának szabadon átválthatónak (konvertibilisnek) kell lennie, az adott valutában kibocsátott hitelviszonyt megtestesítő értékpapíroknak likvideknek kell lenniük. Emellett a tőkepiacnak is átláthatónak kell lennie, szilárd pénzügyi és jogi háttérrel. A kibocsátó ország politikai stabilitása is számít, mivel a politikai instabilitás aláássa a valutába vetett bizalmat. Általánosságban véve tehát a világban dominanciára törekvő ország valutája számára is nemzetközi elismertségre törekszik.

Végül, de nem utolsósorban további két követelmény van, amelyet egy országnak teljesítenie kell ahhoz, hogy világhatalmi státuszt szerezzen: katonai erő, valamint törekvés a világszintű szereplő státuszára. A kettő általában együtt jár, mivel a törekvés hat azokra a döntésekre, amelyek a védelmi kiadásokra vonatkoznak, míg a katonai erő erősíti e törekvést. A tengerekhez való hozzáférés katonai és nemzetközi kereskedelmi szempontból is fontos. A történelem során a birodalmak tengeri hozzáféréssel rendelkeztek, vagy az eredeti földrajzi elhelyezkedésük révén vagy hódítás útján, mint például a törökök és a Habsburgok, az utóbbiaknál házassági szerződések révén is növelték a területet.

Összefoglalva, a jelenlegi globalizált világban, egy országnak ahhoz, hogy irányító szerepet töltsön be az új világrend kialakításában, a következő követelményeknek kell megfelelnie: magas népességszám és nagy földrajzi terület, hozzáférés a tengerekhez, erős gazdaság a GDP méretével mérve, vezető szerep az innovációban és technológiában, gazdasági és devizális erőfölény, katonai erő és a világhatalomra törekvés szándéka. Szándékosan nem beszélünk az állam gazdaságban betöltött szerepéről, mivel a magán- és állami tulajdon megoszlása nem köthető közvetlenül az uralkodó szerephez. Bizonyítékok léteznek azonban arra vonatkozóan, hogy az állam túlzott beavatkozása a gazdaságba fékezi a versenyképességet, de az, hogy az állami szerepvállalás milyen foka kívánatos a világhatalmi státusz eléréséhez, vita tárgyát képezi. Nem foglalkozunk továbbá a politikai berendezkedés szerepével sem. Nyilván bízunk abban, hogy a demokrácia világszerte elterjed, és a világhatalomra törekvő országok demokratikusak lesznek. Ha a modern történelemben Amerika 
vezető szerepe elfogadásra került, sőt a világ sok részén időnként igényelték is azt, az arra vezethető vissza, hogy Amerikára mint szabadságszerető, demokratikus jogállamra tekintettek. Mindazonáltal nincs általános, közvetlen kapcsolat a politikai berendezkedés és a világhatalom között, hiszen volt már példa arra is, hogy diktatúrák és parancsuralmi rendszerek próbálták formálni a nemzetközi berendezkedést.

\section{A versenyzők}

Az 1. táblázat népesség szerint rangsorolja az országokat. Kína 1,4 milliárd és India 1,3 milliárd lakossal a világ két legnépesebb országa, harmadik az Egyesült Államok, 325 millió lakossal, 2017-es adatok alapján. Őket követi Indonézia, Brazília, Pakisztán és Nigéria, 261 millió, 207 millió, 197 millió és 189 millió lakossal, mint a világ következő négy legnépesebb országa. Az Európai Unió - ugyan nem egyetlen ország, hanem 28 országból áll, amelyek egységes piacot alkotnak - összesített népessége kb. 500 millió fő, az eurozóna 19 országának népessége nagyjából 340 millió.

\section{1. táblázat \\ A világ legnépesebb országai, 2017-2019 (millió fö)*}

\begin{tabular}{|c|c|c|c|}
\hline Országok & 2017 & 2018 & 2019 \\
\hline Kína & 1390,1 & 1395,4 & 1400,2 \\
\hline India & 1316,9 & 1334,2 & 1351,8 \\
\hline Európai Unió (EU-28) & 502,5 & 502,9 & 503,4 \\
\hline Egyesült Királyság & 66,0 & 66,5 & 66,9 \\
\hline Visegrádi országok & 63,8 & 63,8 & 63,8 \\
\hline Eurozóna (EA-19) & 338,5 & 338,5 & 338,5 \\
\hline Németország & 82,7 & 82,9 & 83,0 \\
\hline Franciaország & 64,6 & 64,7 & 65,0 \\
\hline Olaszország & 60,6 & 60,5 & 60,7 \\
\hline Egyesült Államok & 325,3 & 327,4 & 329,6 \\
\hline Indonézia & 261,4 & 264,2 & 267,0 \\
\hline Brazília & 206,8 & 208,3 & 209,8 \\
\hline Pakisztán & 197,3 & 201,0 & 204,7 \\
\hline Nigéria & 188,7 & 193,9 & 199,2 \\
\hline Banglades & 163,2 & 164,9 & 166,6 \\
\hline Oroszország & 144,0 & 144,0 & 143,9 \\
\hline Japán & 126,7 & 126,5 & 126,2 \\
\hline \multicolumn{4}{|c|}{ *2018-2019: 2018-as elörejelzés } \\
\hline \multicolumn{4}{|c|}{ Forrás: IMF World Economic Outlook, 2019. április } \\
\hline
\end{tabular}


Területének nagyságát tekintve Oroszország az első, őt követi Kanada, Kína és az Egyesült Államok (2. táblázat). India - a második legnépesebb ország - területének mérete alapján csak a nyolcadik helyen áll. Kanada, Brazília és Ausztrália nagy földterületeket foglalnak el, de viszonylag alacsony népességgel rendelkeznek. Az EU 28 országának összesített területe megközelítőleg 4,4 millió négyzetkilométer, amivel megelőzi Indiát.

\begin{tabular}{|c|c|}
\hline \multicolumn{2}{|c|}{$\begin{array}{l}\text { 2. táblázat } \\
\text { A } 10 \text { legnagyobb ország } \\
\left(\text { ezer } \mathrm{km}^{2}\right)\end{array}$} \\
\hline Országok & Terület \\
\hline Oroszország & 17098 \\
\hline Kanada & 9985 \\
\hline Kína & 9707 \\
\hline Egyesült Államok & 9373 \\
\hline Brazília & 8516 \\
\hline Ausztrália & 7692 \\
\hline Európai Unió (EU-28) & 4388 \\
\hline India & 3288 \\
\hline Argentína & 2780 \\
\hline Eurozóna (EA-19) & 2762 \\
\hline
\end{tabular}

E két adathalmaz alapján az Egyesült Államok uralkodó szerepének megtörésére leginkább alkalmas ország nyilvánvalóan Kína lenne, míg Oroszország és az EU lehetséges kihívók, de előbb nézzük meg a többi követelményt, mielőtt bármilyen következtetést levonnánk.

Egy ország gazdasági ereje több módon mérhető: a GDP nagyságával a világ GDP-jéhez viszonyítva, az egy főre jutó GDP-vel és a világkereskedelemben való részesedésével. 2001 és 2008 között az Egyesült Államok részesedése a világ GDP-jéből 31,5 százalékról 24,2 százalékra csökkent. A kihívó országok közül Kína teljesítménye látványos. 2001-ben a világ GDP-jében 4 százalékos részesedése volt, ami 2018ra majdnem megnégyszereződött, 15,8 százalékot elérve és gyorsan közelítve az Egyesült Államok eredményéhez (3. táblázat). 1980-ban az egy főre jutó reál-GDP a vásárlóerő-paritás alapján negyvenszer magasabb volt az Egyesült Államokban, mint Kínában, míg 2018-ban már csak 3,5-szer volt magasabb annál (4. táblázat). Ez még mindig nagy eltérés, de az elmúlt évtizedekben elképesztő mértékben javult az életszínvonal Kínában. Érdemes megjegyezni, hogy Kína egy főre jutó GDP-jének leggyorsabb felzárkózási időszaka az 1990-es évek elején kezdődött, azaz nagyjából 25 évvel ezelőtt, ami ezt a gyors felzárkózást még inkább figyelemreméltóvá teszi. 
A többi potenciális kihívó részesedése a világ GDP-jéből szintén nőtt, ám a Kínáénál jóval kisebb mértékben. A Visegrádi Négyek $(\mathrm{V} 4)^{2}$ teljesítménye szintén figyelemreméltó. Bár részesedésük a világ GDP-jében alacsony, de 2001 és 2018 között mintegy 30 százalékkal 1,3 százalékra emelkedett, főként Lengyelország - a csoport legnagyobb országa - és Magyarország jelentős teljesítményének köszönhetően.

\begin{tabular}{|c|c|c|c|}
\hline \multicolumn{4}{|c|}{$\begin{array}{l}\text { 3. táblázat } \\
\text { Részesedés a világ GDP-jéből, 2001-2018 között } \\
\text { (százalék, folyó áron, USD-ben) }\end{array}$} \\
\hline Országok & 2001 & 2010 & 2018 \\
\hline Egyesült Államok & 31,5 & 22,7 & 24,2 \\
\hline Európai Unió (EU-28) & 26,8 & 25,8 & 22,1 \\
\hline Egyesült Királyság & 4,8 & 3,7 & 3,3 \\
\hline Visegrádi országok & 1,0 & 1,4 & 1,3 \\
\hline Eurozóna (EA-19) & 19,6 & 19,2 & 16,1 \\
\hline Németország & 5,8 & 5,2 & 4,7 \\
\hline Franciaország & 4,1 & 4,0 & 3,3 \\
\hline Olaszország & 3,5 & 3,2 & 2,4 \\
\hline Kína & 4,0 & 9,2 & 15,8 \\
\hline Japán & 12,8 & 8,6 & 5,9 \\
\hline India & 1,5 & 2,6 & 3,2 \\
\hline Brazília & 1,7 & 3,3 & 2,2 \\
\hline
\end{tabular}

4. táblázat

A vásárlóerő-paritáson mért, egy före jutó reál-GDP hányada az Egyesült Államokéhoz viszonyítva, 1980-2018

\begin{tabular}{l|c|c|c|c}
\hline Országok & $\mathbf{1 9 8 0}$ & $\mathbf{1 9 9 0}$ & $\mathbf{2 0 0 1}$ & $\mathbf{2 0 1 8}$ \\
\hline Kína & 40,38 & 24,25 & 11,52 & 3,46 \\
\hline India & 22,46 & 20,40 & 17,36 & 7,95 \\
\hline Oroszország & n. a. & 1,77 & 3,08 & 2,14 \\
\hline Brazília & 2,56 & 3,43 & 3,98 & 3,88 \\
\hline Japán & 1,40 & 1,20 & 1,34 & 1,42 \\
\hline EU-28 & 1,37 & 1,42 & 1,46 & 1,45 \\
\hline V4 & n. a. & $2,95^{*}$ & 2,74 & 1,89 \\
\hline
\end{tabular}

Megjegyzés: *A V4 országokra adatok 1995-től érhetők el.

Forrás: A 2019. áprilisi IMF World Economic Outlook alapján végzett számítás

\footnotetext{
${ }^{2}$ Visegrádi Négyek: Cseh Köztársaság, Lengyelország, Magyarország, Szlovákia.
} 
Az 1. ábra a globális GDP növekedéséhez való becsült hozzájárulást mutatja 2018ban. Az első 27,5 százalékkal Kína, őt követi az Egyesült Államok (20,4 százalék), az Európai Unió (15,5 százalék) és India (7,6 százalék). Érdemes megjegyezni, hogy az Európai Unión belül a V4 országok hozzájárulása a globális GDP-növekedéshez 2,1 százalék, megelőzve ezzel Oroszországot (1,6 százalék) és Brazíliát (1 százalék).

A főbb országoknak ezen különféle GDP-adatai potenciális világgazdasági befolyásukat jelzik, ami arra ösztönözheti őket, hogy fontos szerepre törekedjenek az új világrend kialakításában.

\section{1. ábra}

Hozzájárulás a globális reál-GDP növekedéséhez, 2018

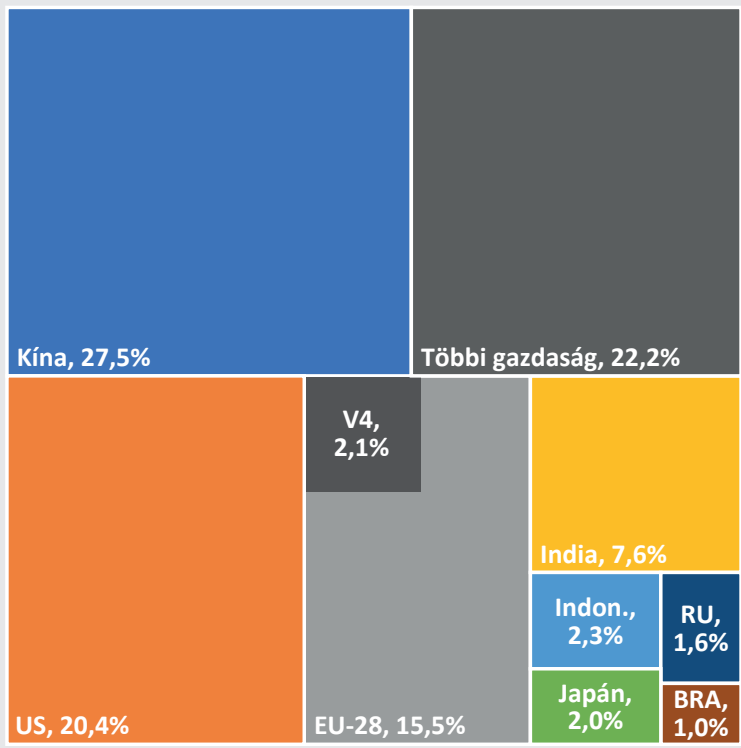

Megjegyzések: V4: Visegrádi Négyek: Cseh Köztársaság, Magyarország, Lengyelország, Szlovákia; Indon.: Indonézia; RU: Oroszország; BRA: Brazília

Forrás: Világbank

Egy országnak a világgazdaságra gyakorolt befolyására vonatkozóan egy másik viszonyítási pont a nemzetközi kereskedelemből való részesedése. Az Egyesült Államok világexportból való részesedése 2001 és 2018 között 11,9 százalékról 8,7 százalékra csökkent, míg Kínáé ugyanezen időszak alatt 4,3 százalékról 13 százalékra nőtt (5. táblázat). Ami az importot illeti, ugyanezen időszak alatt az Egyesült Államok részesedése 18,1 százalékról 13,3 százalékra csökkent, míg Kínáé 3,9 százalékról 10,9 százalékra emelkedett (6. táblázat). Az Egyesült Államok importhányada még így is némileg meghaladja Kínáét, de az export tekintetében Kína megelőzte az Egyesült Államokat. Az EU-28 mintegy 13 százalékos exporthányada nagyjából vál- 
tozatlan maradt, míg az importhányada némileg csökkent, 14,7 százalékról a 13 százalékot kicsivel meghaladó értékre. Ezzel szemben a V4 országok részesedése a világexportban és a világimportban is nőtt, mely folyamat versenyképességük növekedését igazolja.

\begin{tabular}{|c|c|c|c|}
\hline \multicolumn{4}{|c|}{$\begin{array}{l}\text { 5. táblázat } \\
\text { Részesedés a világ exportjából, 2001-2018 } \\
\text { (százalék) }\end{array}$} \\
\hline Országok & 2001 & 2010 & 2018 \\
\hline Kína & 4,3 & 10,5 & 13,0 \\
\hline Európai Unió (EU-28) & 13,0 & 12,0 & 12,8 \\
\hline Visegrádi országok & 1,6 & 2,5 & 3,0 \\
\hline Egyesült Államok & 11,9 & 8,5 & 8,7 \\
\hline Japán & 6,6 & 5,1 & 3,8 \\
\hline Oroszország & 1,6 & 2,6 & 2,3 \\
\hline India & 0,7 & 1,5 & 1,7 \\
\hline Brazília & 1,0 & 1,3 & 1,2 \\
\hline
\end{tabular}

\begin{tabular}{|c|c|c|c|}
\hline \multicolumn{4}{|c|}{$\begin{array}{l}\text { 6. táblázat } \\
\text { Részesedés a világ importjából, 2001-2018 } \\
\text { (százalék) }\end{array}$} \\
\hline Országok & 2001 & 2010 & 2018 \\
\hline Egyesült Államok & 18,1 & 12,8 & 13,3 \\
\hline Európai Unió (EU-28) & 14,7 & 14,3 & 13,3 \\
\hline Visegrádi országok & 1,9 & 2,6 & 2,9 \\
\hline Kína & 3,9 & 9,1 & 10,9 \\
\hline Japán & 5,5 & 4,5 & 3,8 \\
\hline India & 0,8 & 2,3 & 2,6 \\
\hline Oroszország & 0,7 & 1,5 & 1,2 \\
\hline Brazília & 0,9 & 1,2 & 0,9 \\
\hline
\end{tabular}

Egy ország viszonylagos gazdasági ereje értékelhető oly módon is, hogy megnézzük, hogy a világ legnagyobb vállalatai közül az adott ország hányat birtokol vagy múködtet (7. táblázat). A Fortune 500 legnagyobb vállalata között 126 amerikai és 111 kínai vállalat található. Az első tízbe bekerülő négy EU-országban (Németország, Franciaország, Nagy-Britannia és Hollandia) összesen 94 olyan vállalat van, amelyik szerepel az 500 legnagyobb vállalat között. Kína, mint az USA fő kihívója, itt is kimagaslik, míg Európa lemarad. 


\section{7. táblázat}

Az 500 legnagyobb vállalat országonként, 2018

\begin{tabular}{l|c|c}
\hline Országok & Vállalatok száma & Teljes bevétel (millió USD) \\
\hline USA & 126 & 8881646 \\
\hline Kína & 111 & 6765498 \\
\hline Japán & 52 & 2900464 \\
\hline Németország & 32 & 2019931 \\
\hline Franciaország & 28 & 1675121 \\
\hline Egyesült Királyság & 20 & 1133731 \\
\hline Dél-Korea & 16 & 844899 \\
\hline Hollandia & 14 & 960460 \\
\hline Svájc & 14 & 756021 \\
\hline Kanada & 12 & 425169 \\
\hline
\end{tabular}

Forrás: Fortune 500 vállalatok

Mint azt korábban említettük, egy ország valutájának széleskörű használata a nemzetközi pénzügyi tranzakciókban hatalmat és befolyást biztosít a kibocsátó országnak a nemzetközi kapcsolatokban. A 2. és a 3. ábra az amerikai dollár túlsúlyát mutatja a devizatartalékok (62 százalék), a nemzetközi adósságpiac (62 százalék), a hitelügyletek ( 56 százalék) és a devizapiaci forgalom (42 százalék) összetételében. Az euro lemaradó másodikként jelenik meg, kivéve a kereskedelmi forgalmat, amelyben a maga 40 százalékos hányada ugyanakkora, mint az amerikai dolláré. Az Európai Bizottság célja az euro nemzetközi szerepének kiterjesztése a monetáris unió pénzügyi autonómiájának növelése érdekében. Jelenleg az amerikai dollár swap-ügyletek formájában védőhálót biztosit a nemzetközi bankok számára, és az USA amerikai kincstárjegyek és kötvények formájában a biztonságos eszközök legnagyobb szállítója ${ }^{3}$. Annak érdekében, hogy az euro erősebb szerepet játsszon a nemzetközi tranzakciókban, teljesebbé kellene tenni a bankuniót, intézkedések formájában is törekedni a valódi tőkepiaci unió megvalósítására, az Európai Központi Banknak bele kellene egyeznie, hogy szükség esetén nagy összegű euro-swap-ügyleteket köt, és létre kellene hozni egy biztonságos európai pénzügyi befektetési eszközt (safe assets). Mindezt könnyebb mondani, mint megvalósítani az EU összefüggésében, mivel ez a jelenleg tervezettnél erősebb politikai együttműködés melletti elkötelezettséget jelentene, például a kockázatmegosztás terén. Ahhoz, hogy az euro ugyanolyan szerepet töltsön be a nemzetközi monetáris rendszerben, mint az amerikai dollár, arra lenne szükség, hogy EU a globális jelentőségű ügyekben közös külpolitikát kovácsoljon össze, mivel a széttartás gyengíti a valutába vetett bizalmat.

\footnotetext{
${ }^{3}$ Leonard és szerzőtársai (2019)
} 
Jelenleg a kínai renminbi súlya a nemzetközi pénzügyi tranzakciókban nem jelentős, Kína törekvése azonban az, hogy fokozatosan növelje valutája nemzetközi szerepét azáltal, hogy lehetővé teszi renminbi-kötvények kibocsátását mind nemzetközi, mind hazai viszonylatban (Panda kötvények). 2016-tól a renminbi 10,92 százalékos súllyal szerepelt az SDR-kosárban. Ahhoz azonban, hogy Kína valutája kiemelkedőbb nemzetközi szerepet kapjon, szükséges lenne liberalizálni a tőkepiacot, és átláthatóbb pénzügyi szabályozást, valamint árfolyam-politikát bevezetnie. Kína óvatosan halad ebbe az irányba, így várható, hogy a renminbi egyre fontosabb szerepet fog játszani a nemzetközi színtéren, de sok időnek kell még eltelnie ahhoz, hogy a renminbi mint globális valuta az amerikai dollár vagy az euro kihívója lehessen.

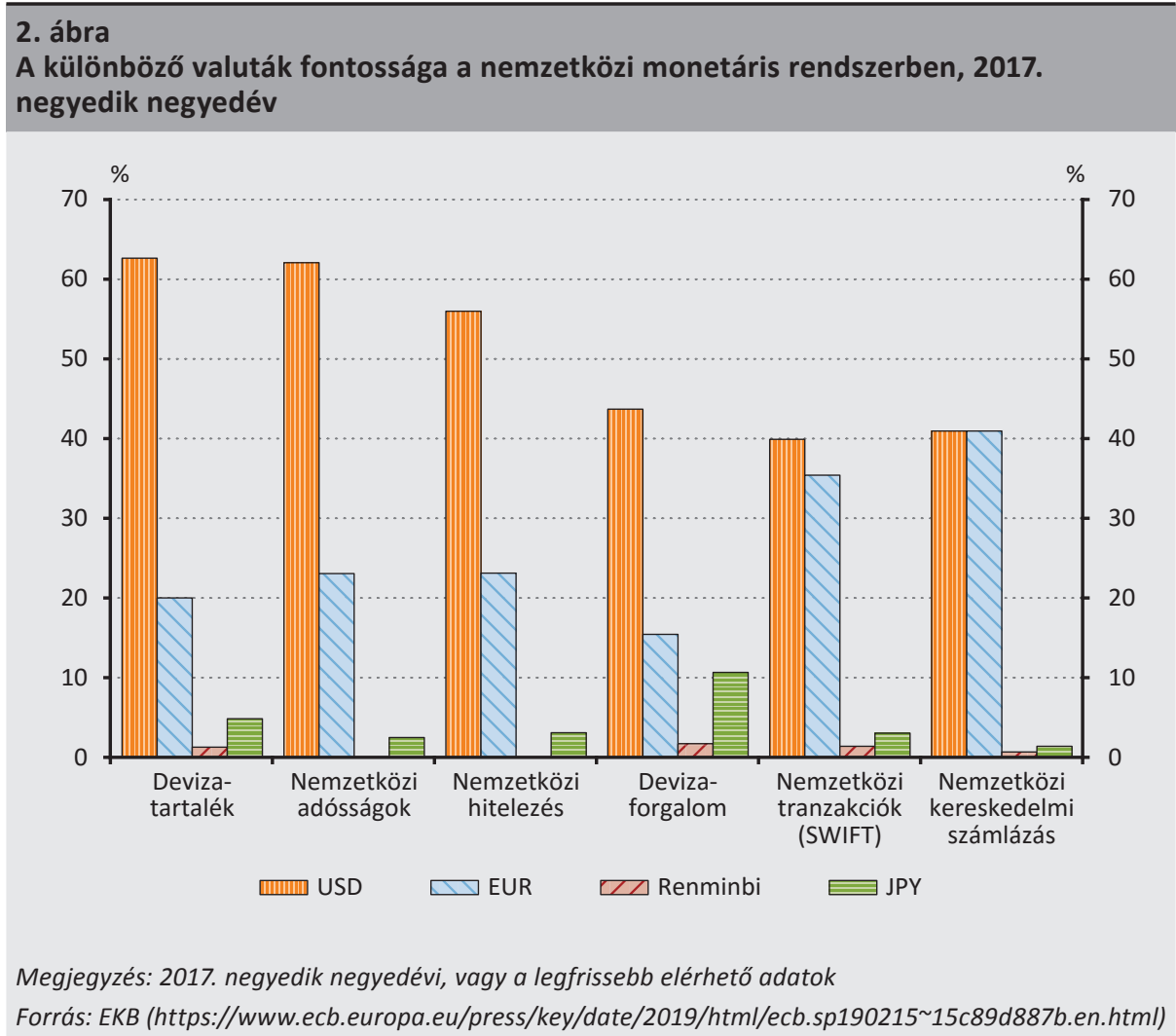




\section{3. ábra \\ Hivatalos devizatartalékok pénznemenként, 2018. negyedik negyedév}
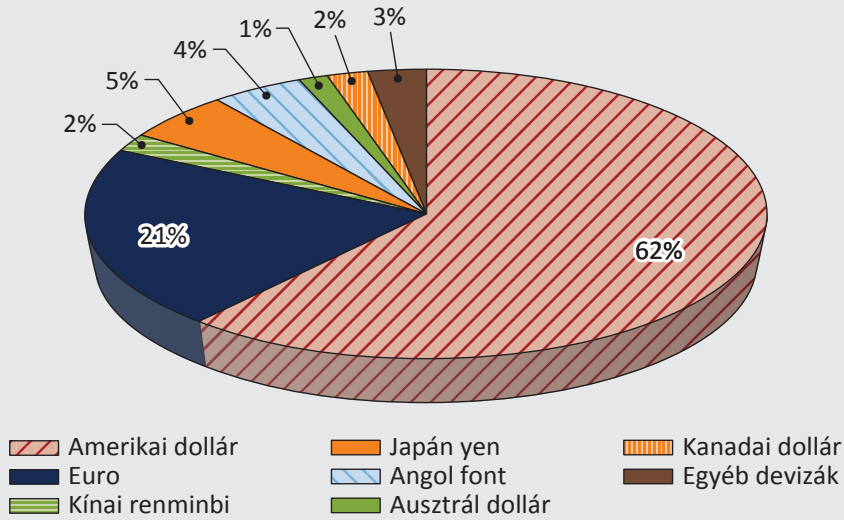

Forrás: Nemzetközi Valutaalap

Végezetül vizsgáljuk meg a katonai kiadásokat. Noha a védelmi kiadások sokat elmondanak egy ország katonai erejéről, ez a valós katonai erőnek csak tökéletlen mutatója, ugyanis a hadsereg fizetése és ugyanazon fegyverzet előállítási költsége országonként rendkívül eltérő lehet. A valós katonai erőt a fegyverek típusa és rendelkezésre álló számuk határozza meg, és jellemzően az, hogy egy ország rendelkezik-e nukleáriscsapás-mérő képességgel, hatalmas tengeri haderővel, katonai támaszpontokkal szerte a világban stb. Ezen túlmenően, tekintettel arra, hogy a katonai kiadások általában titkosak, a rendelkezésre álló számok nem feltétlenül mutatják a védelmi kiadások valódi mértékét. Ezeket a fenntartásokat figyelembe véve, az évről évre, rendszeresen a katonaságra költött pénzösszeg jól mutatja egy ország törekvéseit.

A 8. táblázat bemutatja, hogy dollárban mérve messze az Egyesült Államok védelmi kiadásai a legmagasabbak (706 milliárd USD, ami a 2018-as GDP 3,4 százaléka), őt követi az EU-28 (263 milliárd USD, vagy a GDP 1,4 százaléka), majd Kína (kb. 250 milliárd USD, vagy a GDP 1,9 százaléka), India (66 milliárd USD, vagy a GDP 2,4 százaléka) és Oroszország (61 milliárd USD, vagy a GDP 3,8 százaléka) következik. 2011 és 2017 között a védelmi kiadások Kína kivételével a vizsgált országok mindegyikében csökkentek, és csak néhányukban nőttek 2018-ban. Kínában 2011 és 2018 között a katonai kiadások több mint 80 százalékkal emelkedtek egyes becslések szerint. Kína bővíti tengeri haderejét és megkezdte a tengeri bázisok kiépítését. A vizsgált országok közül az Egyesült Államok, Oroszország, az Egyesült Királyság, Franciaország, Kína és India rendelkezik atomfegyverekkel (ezen országcsoportokon kívül, Izrael és Pakisztán is rendelkezik atomfegyverrel). 


\begin{tabular}{|c|c|c|c|c|c|c|c|c|}
\hline \multicolumn{9}{|c|}{$\begin{array}{l}\text { 8. táblázat } \\
\text { Védelmi kiadások, 2011-2018 } \\
\text { (millió USD) }\end{array}$} \\
\hline Országok & 2011 & 2012 & 2013 & 2014 & 2015 & 2016 & 2017 & 2018 \\
\hline Egyesült Államok & 740744 & 712947 & 680856 & 653942 & 641253 & 656059 & 685957 & 706063 \\
\hline Európai Unió (EU-28) & 260639 & 242432 & 247420 & 249073 & 217216 & 219077 & 230641 & 262991 \\
\hline Egyesült Királyság & 62852 & 58016 & 62258 & 65658 & 59492 & 56964 & 55344 & 61508 \\
\hline Franciaország & 53441 & 50245 & 52316 & 51940 & 43474 & 44191 & 46036 & 52025 \\
\hline Németország & 48140 & 46470 & 45931 & 46102 & 39813 & 41590 & 45580 & 51009 \\
\hline Olaszország & 30223 & 26468 & 26658 & 24448 & 19566 & 22373 & 23852 & 25780 \\
\hline Kína & 137967 & 157390 & 179880 & 200772 & 214093 & 216031 & 227829 & 249997 \\
\hline Oroszország & 70238 & 81469 & 88353 & 84697 & 66419 & 69245 & 66527 & 61388 \\
\hline Japán & 60762 & 60012 & 49024 & 46881 & 42106 & 46471 & 45387 & 46618 \\
\hline India & 49634 & 47217 & 47404 & 50914 & 51295 & 56638 & 64559 & 66510 \\
\hline Brazília & 36936 & 33987 & 32875 & 32660 & 24618 & 24225 & 29283 & 27766 \\
\hline
\end{tabular}

\section{Egy többpólusú világrend felé}

A történelem megtanította, hogy időről időre megjelennek vezető államok, de végül kihívókra lelnek. Egy uralkodó világhatalom hanyatlása és egy új vezető állam megjelenése általában hosszú időt vett igénybe, gyakran évszázadokat. A mostani, gyors technológiai változásokkal és növekvő, globális versennyel jellemzett világban a geopolitikai eltolódások lényegesen gyorsabbak lesznek, mint a korábbi évszázadokban.

Napjaink fejleményeit vizsgálva nyilvánvalónak tűnik, hogy az Egyesült Államok globális eseményeket formáló és irányító viszonylagos hatalma csökkenőben van. Az a „Pax Americana”, amelyet a Il. világháború óta ismerünk, a végéhez közeledik. Ez azonban semmiképpen sem jelenti azt, hogy az USA ne maradna a világ egyik vezető hatalma az elkövetkező évtizedekben. Amerika erős gazdasággal rendelkezik, ami az innováció és technológia terén betöltött vezető szerepén és a tehetségeknek a világ minden pontjáról való odavonzási képességén alapul. Hatalmas mennyiségú természeti kinccsel rendelkezik, és meghatározó szerepet játszik a nemzetközi kereskedelemben, míg az amerikai dollár dominanciája a nemzetközi monetáris rendszerben olyan előnyökhöz juttatja, amelyeket jelenleg egyetlen más ország sem élvez. Az ország két óceán között terül el, és megvan az eszköze és az akarata, hogy továbbra is a legerősebb haderő maradjon. Zbigniew Brzezinski újabb dimenzióval egészíti ki az amerikai erőt, amelyet „visszaható mobilizációnak” nevez, és a társada- 
lom mozgósítását érti alatta veszélyhelyzetben, ami megerősíti a nemzeti egységet. ${ }^{4}$ Brzezinski az „Emlékezz Pearl Harborra” jelmondatot idézi, amely mozgásba hozta az ország háborús erőfeszítéseit. E nemzeti egység közelmúltbeli példája a 9/11, amikor autósok tízmilliói tǔzték ki a lobogót, olyan sokan, hogy még egy magyar vállalat is kapott megrendelést amerikai zászlók szállítására.

Amerikának meggyőződése, hogy a világ vezetésére hivatott. Amerika „kivételessége" (American exceptionalism) berögzült az Egyesül Államok vezetőibe, és a lakosság jó része is osztja azt. Ez a szabadságért, demokráciáért és egyenlőségért vívott harccal jellemzett történelmében gyökerezik, és legjobban Abraham Lincoln gettysburgi beszédével ragadható meg, amikor kihirdette „a néptől, a nép által, a népért való hatalmat", amelyet a Jognyilatkozat ${ }^{5}$ fontos értékként őriz. Mint Robert Kagan írja: „az elnökök és politikusok a 'szabad világ vezetője' (Barack Obama), a 'nélkülözhetetlen nemzet' (Madelaine Albright), amelyre a 'világ számít' a 'globális vezetés' tekintetében (Hillary Clinton) kifejezéseket használják" ${ }^{6}$ még napjainkban is. Donald Trump „Amerika az Első” szlogenje azonban azt sugallja, hogy Amerika egyre kevésbé akarja magára vállalni a globális vezetés felelősségét, még akkor is, ha egyébként kész bevetni gazdasági és katonai erejét a saját gazdasági és biztonsági céljainak megvalósításáért. Jó példa arra, hogy az Egyesült Államok gazdasági hatalmát használja fel vélelmezett érdekeinek védelmére, a Kínával folytatott kereskedelmi háború, vagy az EU-ból az Egyesült Államokba irányuló import vámterhelésével való fenyegetőzés, és - mint az európai egység megbontásának eszköze - a Brexit Egyesült Államok általi támogatása, amit egy, az Egyesült Királyságnak tett ajánlattal fejelt meg egy szabadkereskedelmi megállapodás gyorsított megkötésére vonatkozóan.

Az adatokból és a jelen tanulmányban bemutatott értekezésből kibontakozó kép szerint Kína áll a legközelebb ahhoz, hogy az Egyesült Államok gazdasági erőfölényét megrengesse. Nagyszámú népessége, hatalmas területe, gyors gazdasági növekedése, az innováció és a technológiai fejlesztések terén tapasztalt ereje, valamint a nemzetközi kereskedelemben betöltött vezető szerepe mind arra predesztinálják Kínát, hogy világvezetővé váljon. Világos az a törekvése is, hogy részt vegyen az új világrend kialakításában. Míg az Egyesült Államok erőfölénye az olyan nemzetközi szervezetekben, mint a Nemzetközi Valutaalap, a Világbank és az ENSZ, továbbra is uralkodó, Kína több mint 300 nemzetközi és regionális szervezet tagja, és súlya e szervezetekben nő. Az Egy Övezet, Egy Út kezdeményezés és a 17+1 ${ }^{8}$ együttműködés, valamint a kínai beruházások az Egyesült Államokban, Európában, Ázsiában,

${ }^{4}$ Brzezinski (2012:60)

${ }^{5} \mathrm{Az}$ amerikai alkotmányban rögzített Bill of Rights

${ }^{6}$ Kagan (2012:14)

${ }^{7}$ America First

${ }^{8}$ 17+1 együttműködés Kína kezdeményezése azzal a céllal, hogy erősítse és bővítse az együttműködést a közép-kelet-európai országokkal. 12 EU-tagállamot és 5 balkáni országot foglal magában. 
Afrikában és Dél-Amerikában Kína azon stratégiáját sejtetik, hogy jóval a nemzeti határai által szabta korlátokon túl terjessze ki gazdasági kapcsolatait, és az egész világot átfogja. Egy igazi világvezetőnek erős hadseregre van szüksége az ambíciói támogatásához, és Kína fejleszti katonai erejét, habár hangsúlyozza, hogy az kizárólag védelmi célokat szolgál, és nincs bizonyítékunk ennek ellenkezőjére. Kihívást jelent, hogy Kína a népessége elöregedésével szembesül a több évtizedes „egy-gyermek politika” eredményeképpen. Ez a politika a közelmúltban módosításra került, de sok évnek kell eltelnie, mielőtt az elöregedés megállna. Kínának megvan a lehetősége és a képessége, hogy növelje termelékenységét, ami ellensúlyozhatja a csökkenő munkaerőt, de az öregedés olyan tényező, amely korlátozni fogja a növekedést. Ez azonban nem fogja megakadályozni Kínát abban, hogy világhatalommá váljon.

Oroszország lehet a másik kihívó, és nyilvánvalóan szerepet akar vállalni a kialakulóban lévő új világrend formálásában. Rendelkezik katonai erővel, de a gazdasága egyelőre viszonylag gyenge lábakon áll, erősen támaszkodva az olaj- és gáziparra. Ez idővel bizonyára változni fog, így Oroszország is azon hatalmak közé sorolandó, amelyek meghatározó szerepet fognak játszani az új, többpólusú világrendben.

Az Európai Unió rendelkezik a világ ügyeiben befolyásos szereplővé váláshoz szükséges mérettel, gazdasági és innovációs erővel, valamint haderővel, de az a tény, hogy nem rendelkezik közös külpolitikával és egységes véleménnyel az olyan kérdésekben, mint a közös védelmi politika és az egész EU-ra kiterjedő költségvetés makrogazdasági szerepe, korlátozza a befolyását. Sajnos a Brexit éket ver az Egyesült Királyság és az EU közé, ezzel törést okozva Európa egységében. Henry Kissinger gyászos véleménnyel van Európáról, amikor azt mondja, hogy „Európa fontossága folyamatosan gyengül Európa globális küldetéstudatának elvesztése miatt". ${ }^{9}$ Carl Bildt, Svédország korábbi miniszterelnöke helyesen javasolja, hogy az EU „dolgozzon ki egy európai szintü politikai eljárást, amely fejleszti a független cselekvés képességét, és egyúttal új mechanizmusokat vezet be a tagállamok közötti egység ösztönzésére" ${ }^{10}$ Tekintettel a tagállamok eltérő érdekeire, az bele fog telni egy kis időbe. Mindazonáltal Európa hasznosan tud közvetíteni a regionális konfliktusok megoldásában, valamint kezdeményezhet és támogathat jó célokat, mint amilyen például a környezetvédelem.

A világhatalmi politika jövője a technológia. „Ebben az évszázadban az adatok és a technológiai függetlenség, nem pedig a nukleáris robbanófejek fogják eldönteni a hatalom és a vagyon globális eloszlását", jegyezte meg Joschka Fischer, Németország korábbi külügyminisztere. ${ }^{11}$ A platformgazdaság, mint amilyen a Microsoft, az Apple, az Alibaba, stb., a mesterséges intelligencia és a Big Data birodalmában Európa jócskán lemaradt harmadik az USA és Kína mögött. Ahogy Matolcsy György

\footnotetext{
${ }^{9}$ Henry Kissinger, Nobel-díj Fórum, Oslo, 2016. december 11.

${ }^{10}$ Fischer (2019)

${ }^{11}$ Bildt (2019)
} 
(2019:32) írja: „A(a) disztruptiv, új technológiák képesek globálisan újraosztani a hatalmat, a gazdasági erôt és a pénzügyi forrásokat [...] A(a)z európai elit kihagyta az amerikai lehetőséget, hogy együtt nyerjenek a disztruptiv, új technológiai folyamatokban". Ez részben az egységes piac hiányának következménye a kutatás és tőkefinanszírozás terén. Ahhoz, hogy megfeleljen a jövő kihívásainak és fenntarthassa a versenyképességét, Európának technológiai átállásra és átképzésre van szüksége. Miközben minden egyes ország felelős e folyamatban, elengedhetetlen az EU-szintű kormányzat támogatása. Kína esetében a kormány innovációban betöltött meghatározó szerepe megkérdőjelezhetetlen. Az Egyesült Államokban a kormánynak az innováció támogatásában nélkülözhetetlen szerepe volt az űrkutatásra és honvédelemre fordított kiadások formájában. Az EU-nak dolgoznia kell a digitális függetlenség elérésén, és ez nem valósítható meg összehangolt, EU-szintű politika nélkül.

A kérdés az, hogy miképpen fog müködni a többpólusú világrend. Béke vagy háború lesz? Atombéke? Vagy regionális háborúk, ahol a versengő vezető államok érdekei ütköznek? Lesznek-e élesen kirajzolódó földrajzi területek, amelyeket egy konkrét világhatalom ural? Elképzelhető-e egy olyan világrend, amelyben Kína tölt be uralkodó szerepet Ázsiában, az Egyesült Államok Latin-Amerikában, Oroszország Eurázsiában és Európa Afrikában? Vagy akarják-e majd a versengő vezető államok az egész világ eseményeit formálni? Fel kell tenni ezeket a kérdéseket, és mindenki töprenghet a válaszon. Egy dolog biztosnak tűnik: az Egyesült Államok hegemóniája a világ felett a kihívók erősödésével párhuzamosan gyengülni fog. Kína és Oroszország, és később talán India befolyása a világ eseményeinek alakulására nőni fog. Európának egységesebbé kell válnia a fő politikai területeken, ha meg akarja védeni érdekeit, és meg akarja őrizni jogos helyét a világ vezetői között egy egyre versengőbb környezetben. Az EU-nak szüksége van a kínai kapcsolatok kiépítésére, miközben megőrzi az Egyesült Államokkal kialakult hagyományos kapcsolatát is. Az Egy Övezet, Egy Út kezdeményezést és a 17+1 együttmüködést nem szabad Európa keleti és nyugati részei közötti megosztó tényezőként kezelni - ahogy azt egyesek szeretik bemutatni -, hanem inkább lehetőségként kell tekinteni a Kínával való szorosabb kapcsolatok kialakításához.

Mindazonáltal szükség van a világot vezető, erős és demokratikus országokra a béke és a rend fenntartásához a világban. Befejezésül álljanak itt Robert Kagan szavai: „Nem létezik világrend annak megőrzését, szabályai kialakítását, intézményei védelmezését, a gazdasági rendszer hajtóerejének megvédését és a béke fenntartását célul tüző hatalom nélkül." ${ }^{12}$ A jövőben ez két vagy három vezető állam között megosztott hatalom lesz, és az ő feladatuk lesz, hogy fenntartsák a Kagan által említett világrendet.

${ }^{12}$ Kagan (2012:139) 
Végezetül, ne feledjük el, hogy a V4 országai az évszázadok során gyakran keveredtek bele az Európa feletti dominanciájuk kiterjesztéséért küzdő hatalmak harcaiba. Ezek az országok ma már az Európai Unió tagjai az európai kereskedelmi útvonalak kelet-nyugati és észak-déli kereszteződéseinél. Emellett a NATO-nak is értékes tagjai. A V4 országok és a többi közép- és kelet-európai ország létfontosságú érdeke, hogy mérlegeljék, milyen geopolitikai változások várhatóak az elkövetkező évtizedekben.

\section{Felhasznált irodalom}

Bildt, C. (2019): Europe risks irrelevance in the age of great power competition. Financial Times, July 19.

Brzezinski, Z. (2012): Strategic Vision. Basic Books, New York.

Eichengreen, B. (2011): Exorbitant Privilege. The Rise and Fall of the Dollar and the Future of the International Monetary System. Oxford University Press.

Fischer, J. (2019): Who will win the twenty-first century? Project Syndicate, July 30.

Friedman, G. (2012): The Next Decade, Empire and Republic in a Changing World. Anchor Books, Random House, New York.

Kagan, R. (2012): The World America Made. Alfred A. Knopf, New York.

Kennedy, P.M. (1988): The Rise and Fall of Great Powers 1500-2000. Random House, New York.

Kissinger, H. (1979): White House Years. Little Brown \& Co, Boston, Massachusetts, U.S.A.

Kjellén, J.R. (1917): Der Staat als Lebensform. Leipzig.

Leonard, M. - Pisani-Ferry, J. - Ribakova, E. - Shapiro, J. - Wolff, G. (2019): Redefining Europe's economic sovereignty. European Council on Foreign Relations, Policy Contribution, Issue no. 9, June. https://www.ecfr.eu/page/-/2_Redefining_Europe's_economic_sovereignty.pdf

Matolcsy, Gy. (2019): American Empire vs. European Dream. The Failure of the Euro. Pallas Athéné Könyvkiadó, Budapest.

Modelski, G. (1988): Long Cycles in World Politics. Macmillan, London. https://doi. org/10.1007/978-1-349-09151-5

Ratzel, F. (1897): Politische Geographie. München und Leipzig, R. Oldenbourg.

Thomson, W.R. (1988): On Global War: Historical-Structural Approaches to World Politics. University of South Carolina Press, Columbia.

Szilágyi István (2018): A geopolitika elmélete. Pallas Athéné Könyvkiadó, Budapest. 